\title{
THE EFFECT OF SCIENTIFIC APPROACH OF PROBLEM BASED LEARNING (PBL) MODELS AND SOCIAL SKILLS ON STUDENT LEARNING OUTCOMES PPKN SUBJECTS CLASS V AT SDN 106161 LAUT DENDANG YEAR 2020/2021
}

\author{
Ayu Listian Tarigan ${ }^{1}$ \\ State University of Medan, Indonesia \\ Email : ayutarigan170@gmail.com \\ Deny Setiawan'2 \\ State University of Medan, Indonesia \\ Daulat Saragi ${ }^{3}$ \\ State University of Medan, Indonesia
}

\begin{abstract}
The purpose of this study is to determine: (1) To determine the effect of applying the scientific approach to the Problem Based Learning (PBL) model on student learning outcomes. (2) To determine the effect of Social Skills on student learning outcomes (3) To determine the interaction of the Scientific Approach Model Problem Based Learning (PBL) and social skills in influencing student learning outcomes of Civics. The population of this study was all fifth grade students at SDN 106161 Laut Dendang for the academic year 2020/2021. The sampling technique in this study was taken randomly using a lottery, determined 2 (two) classes as the experimental group, namely 1 (one) class being the Scientific Approach Treatment class and the 2nd class being the expository learning treatment class. The determination of the experimental class and the control class is the Problem Based Learning (PBL) model in the VA class 30 Students and expository learning model in VB. class 28 Students. The data analysis technique used was two-way ANOVA at a significance level of $=0.05$, followed by the Scheffe test. The results obtained: (1) the average PPKn learning outcomes of students with Problem Based Learning (PBL) learning is 24.37 higher than students with expository learning of 19.46. (2) the average civics learning outcomes among students who have high social skills get an average score =
\end{abstract}


24.15, while the civics learning outcomes of students who have low social skills get an average score $=20.25$ (3) there is no interaction between the use of the learning model and students social skills (high and low), namely the high social skills group (26.69), and the low social skills group (22.59), which is greater than the students who are taught with expository learning, namely the high social skills group (21.62), and the low social skills group (17.60). The results of data analysis concluded that students with high social skill characteristics used the Problem Based Learning (PBL) learning model and obtained a high average. While low social skills using the Expository model will get a low average. The implication of this research is that efforts to improve the teaching and learning process provide a more meaningful learning experience for students, one of the efforts that teachers can do is through the use of Problem Based Learning (PBL).

Keywords: $\quad$ Learning Model Problem Based Learning (PBL), Social Skills, PPKn Learning Outcomes

\section{A. Introduction}

Learning is basically an active student activity in building meaning or understanding of the teaching material. Teachers in the teaching process encourage students to use their authority in building positive ideas, ideas, and attitudes. The responsibility for learning lies with the students, and teachers create situations that enable students to take initiative, be motivated and take responsibility for lifelong and sustainable learning.

Implementation of the 2013 curriculum in learning with a scientific approach is a learning process designed in such a way that students actively construct concepts, laws or principles through the stages of observing (to identify or find problems), formulate problems, propose or formulate hypotheses, collect data in various ways. techniques, analyze data, draw conclusions and communicate the "found" concept, law or principle. Changes in process standards mean changes in teaching and learning strategies. Teachers are required to design and manage a fun [612] 
active learning process. Students are facilitated to observe, ask questions, process, present, conclude and create. The teaching and learning process uses a scientific approach by prioritizing discovery learning, problem based learning and project based learning. In the 2013 curriculum, the assessment is directed at the use of authentic assessment by strengthening the use of benchmark reference assessments to assess basic competencies and core competencies.

There are several things that make student learning outcomes not optimal, one of the contributing factors is the teacher. The weaknesses of teachers analyzed in strengthening the quality of the learning process include: (1) They do not act as facilitators but act more and act as the only source of learning, (2) they tend to appear not as educators who can develop integrated dimensions. intellectual, emotional and social, (3) tends to act as a provider of learning materials yet to act as learning, (4) has not been able to carry out optimal classroom management, acts more as a presenter of book information, (5) has not acted directly planned to form thinking skills and student value system, (6) acts more as a teacher so that they do not act much as a role model, (7) has not optimally provided convenience for students in learning. The success of learning in terms of achieving competency standards is very less inviting students to be able to carry out activities to observe problems related to the material being studied, either directly or through the media.

The Problem Based Learning (PBL) model details the use of real life problems as something that students must learn to train and improve critical thinking and problem solving skills and gain knowledge of important concepts, where the teacher's task must focus on helping students achieve social skills. According to Wanhar (2015:28) Problem Based Learning Models are: Centralized learning through relevant issues. 
Centralized because it contains scenarios, unit themes that put back the desired learning. The purpose of this learning process is the ability of students to solve problems, describe problems and revise them when making presentations so that they will add information according to their competence. One method that is widely adopted to support a studentcentered learning approach that can empower students.

Based on the results of observations made in class V SDN 106161 Laut Dendang that the implementation of learning is still a concern. In Civics learning, the learning process only creates students who are able to master cognitive theory, namely understanding and memory.Student scores are still in the sufficient category. This is due to the lack of students understanding of the concept of Civics learning. They consider Civics lessons as boring subjects, another problem raised is the teacher's lack of attention in developing learning skills.

\section{B. Method}

\section{Research Location and Time}

The location of the research is SDN 106161 Laut Dendang, Class V (Five) in the even semester of the 2020/2021 academic year. The research schedule was carried out according to the admission schedule in question and the teacher teaching in giving treatment was the Integrated Thematic teacher at SDN 106161 Laut Dendang.

\section{Population and Research Sample}

The population of this study was all fifth grade students at SDN 106161 Laut Dendang for the academic year 2020/2021. This is in line with the statement Sugiyono (2010:143) population is a generalization area consisting of: objects or subjects that have certain qualities and characteristics that are determined by researchers to be studied and then 
drawn conclusions. Each class has the same characteristics, meaning that every student uses the same curriculum. Research population totaling 88 students and distributed into three classes

The sampling technique in this study was taken randomly using a lottery, determined 2 (two) classes as the experimental group, namely 1 (one) class being the Scientific Approach Treatment class and the 2nd class being the expository learning treatment class. The determination of the experimental class and the control class is the Problem Based Learning (PBL) model in the VA Class 30 Students and expository learning model in VB class 28 Students. Then based on social skills, classes are distinguished between groups of students with high social skills and low social skills.

\section{Research Procedure}

The implementation of the treatment in this study was adjusted to the learning activities that took place at SDN 106161 Laut Dendang in class $\mathrm{V}$. Materials and learning materials were prepared referring to the Scientific learning approach and the learning model of material repository Events around the proclamation in Class V. this research, are as follows:

1. Initial Stage (Preparation and Planning)

2. Implementation Stage

3. Reporting stage, compiling data analysis and conclusions of research results.

\section{Instruments and Data Collection Techniques}

1. Learning Outcome Test

2. Social Skills Instrument Trial

\section{Inferential Statistical Analysis}

1. Normality Test

2. Homogeneity Test

3. Statistical Hypothesis Test 


\section{Finding and Discussion}

\section{Result}

a. Student Civics Learning Outcomes Score Using learning Problem Based Learning (PBL)

Based on the results of research conducted at the end of the experiment, it showed that for the treatment class, the students of class $A_{1}$ the highest score was 35 and the lowest score was 14 . The frequency distribution was analyzed using the Sturges technique and obtained a range of 21 , the number of class intervals 6 , and the length of class 4 .

Students (13.333\%) are in the interval $14-17,5$ students $(16.667 \%)$ are in the interval $18-21,8$ students $(26.667 \%)$ are in the interval $22-25,7$ students $(23,333 \%)$ are in the interval $26-29$, it can be seen that 4 students (13.333\%) is between the interval $30-33$, and 2 students $(6,667 \%)$ is in the interval $34-37$. Distribution of scores. The results of the Civics learning outcomes above can be described by histograms as statistical diagram data.

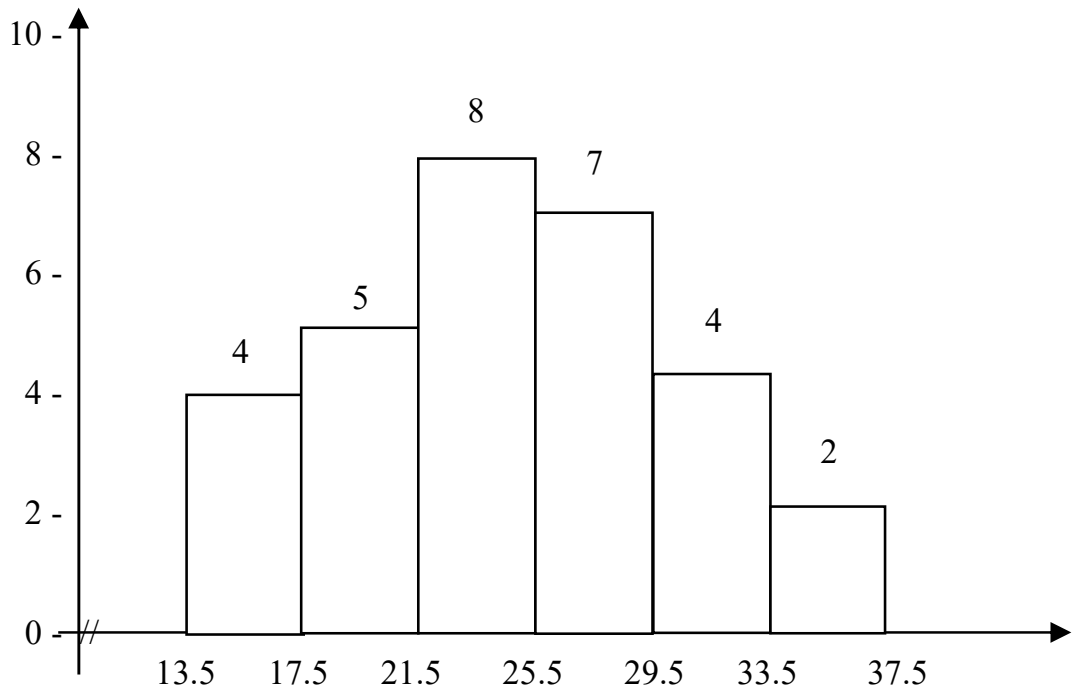

Figure 1. Histogram of Civics Learning Outcomes of Students Taught Using Learning Problem Based Learning (PBL) 
b. Civics Learning Outcomes Scores of Students Taught Using Expository Learning

Based on the results of the research conducted at the end of the experiment, it showed that for the treatment class, namely students of class $\mathrm{A} 2$, the highest score was 30 and the lowest score was 10 . The frequency distribution analyzed using the Sturges technique obtained a range of 20, many classes of intervals 6 , and class length 4 . It can be seen that: 4 students $(14.29 \%)$ are in the interval $10-13,7$ students $(25.00 \%)$ are in the interval $14-17,7$ students $(25.00 \%)$ are in the interval $18-21$, 4 students (14.29\%) are in the interval $22-25,5$ students $(17.86 \%)$ are in the interval $26-29$, and 1 student (3.57\%) is in the interval of $30-33$. The distribution of the scores of the students Civics learning outcomes above can be described in a histogram as statistical diagram data as shown in Figure 2 below:

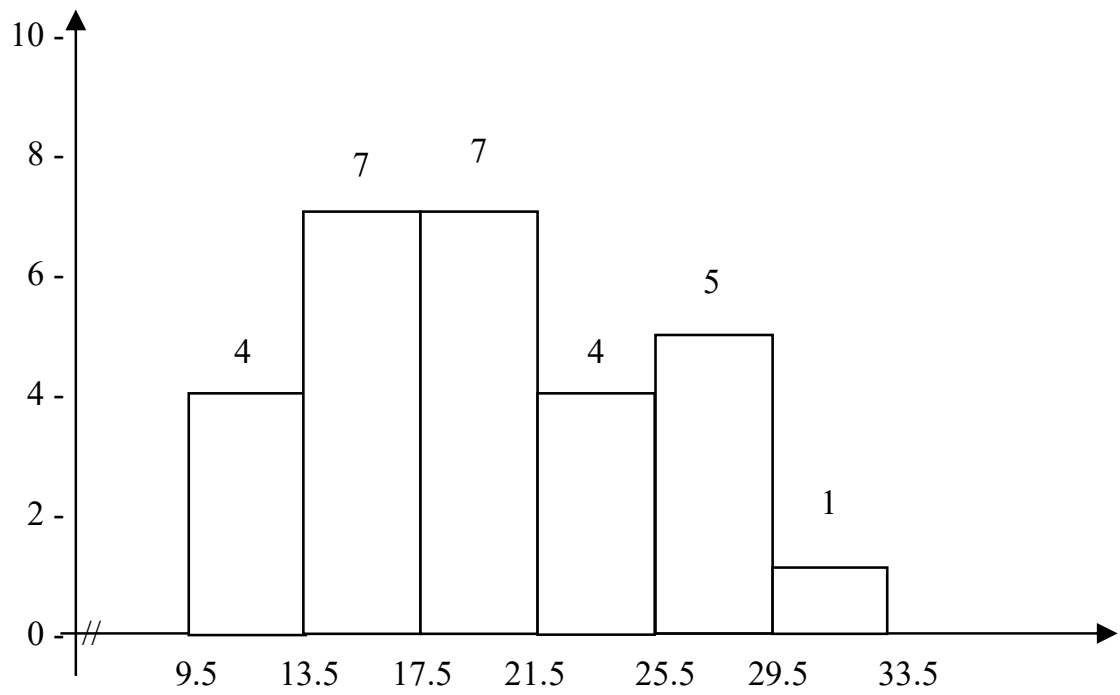

Figure 2. Civics learning outcomes of students who are taught using expository learning 
c. Student Social Skills Score High Social Skills Taught Using learning Problem Based Learning (PBL)

Based on the results of research conducted at the end of the experiment, it showed that for the treatment class the highest score was 35 . and the lowest score was 18 . The frequency distribution was analyzed using the Sturges technique to obtain a range of 17 , the number of class intervals 5 , and the length of class 4.

2 students $(15,385 \%)$ are in the interval 18-21, 4 students $(30,769 \%)$ are in the interval $22-25,3$ students $(23,077 \%)$ are in the interval $26-29,2$ students (15,385\%) are in the interval $30-33$, and 2 students $(15,385 \%)$ are in the interval $34-37$, high social skills learning students who use Problem Based Learning (PBL). The distribution of students social skills scores using Problem Based Learning (PBL) students above can be described by histograms as statistical diagram data as shown in Figure 3 below:

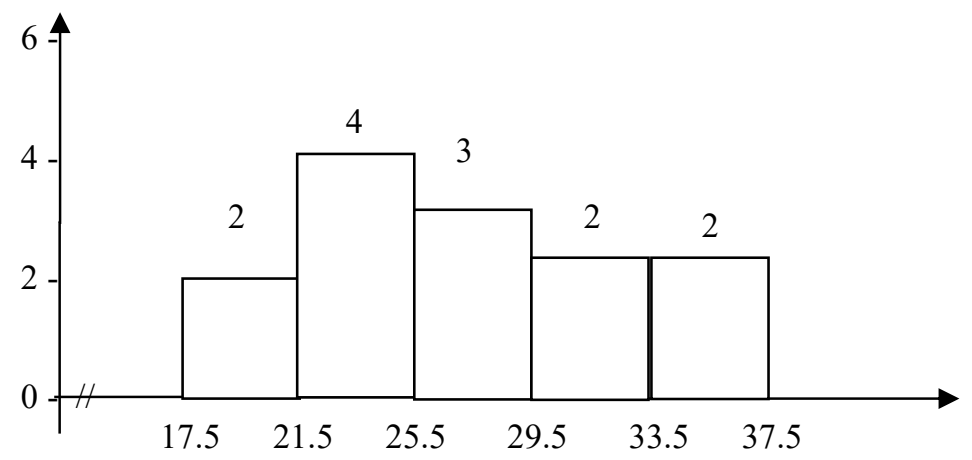

Figure 3. Histogram of High Social Skills of Students Using Learning Problem Based Learning (PBL)

d. High Social Skills Score Students taught using Expository learning

The results of the research conducted at the end of the experiment showed that for the treatment class, the highest score was 30 and the lowest score was 14 . The frequency distribution was analyzed [618] 
using the Sturges technique. 16, the number of interval classes is 5 , and the length of the class is 4

3 students $(23,077 \%)$ are in the interval 14-17, 4 students $(30,769 \%)$ are in the interval $18-21,2$ students $(15,385 \%)$ are in the interval $22-25,3$ students $(23,077 \%)$ are in the interval $26-29$, and 1 student $(7.6923 \%)$ are in the interval $30-33$, students social skills are taught using expository learning. The distribution of the scores of social skills of students who are taught by using the expository learning of students above can be described as a histogram as statistical diagram data as shown in Figure 4 below:

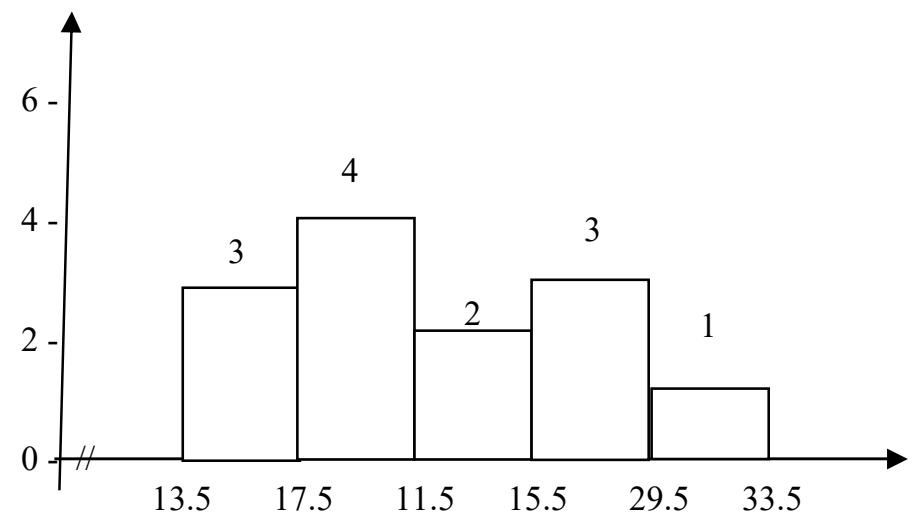

Figure 4. Histogram High Social Skills Students taught by Using Expository learning

e. Frequency Distribution of Civics Learning Outcomes Low Social Skills taught using Problem Based Learning (PBL)

The results of the research conducted at the end of the experiment showed that for the treatment class the highest score was 31 and the lowest score was 14 . The frequency distribution analyzed using the Sturges technique obtained a range of 17 , many classes of intervals of 5 , and length of class 4 . 
4 students (23.53\%) are in the interval $14-17,3$ students $(17.65 \%)$ are in the interval $18-21,4$ students $(23.53 \%)$ are in the interval $22-25,4$ students (23.53\%) are in the interval $26-29$, and 2 students $(11.76 \%)$ is in the interval of $30-33$. The distribution of scores. The results of Civics learning outcomes for students with low social skills who are taught using Problem Based Learning (PBL) above can be described as histograms as statistical diagram data as shown in Figure 5 below:

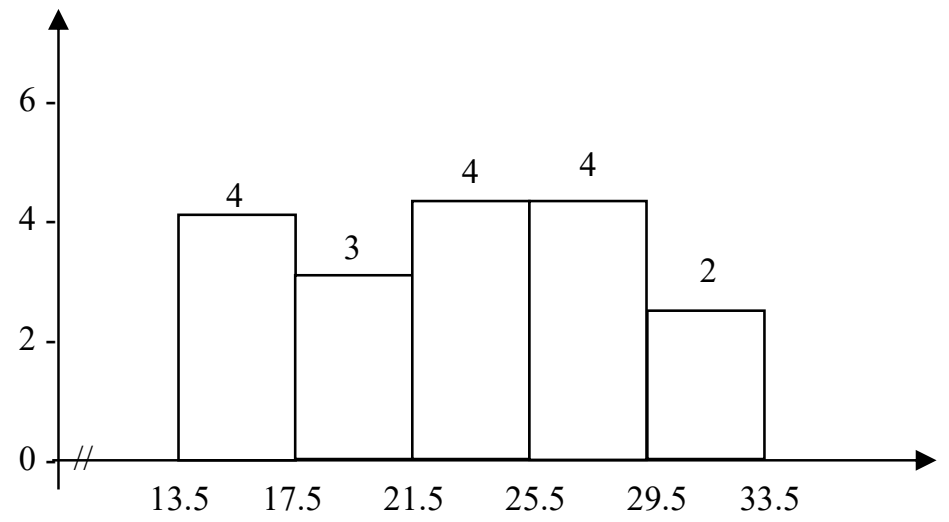

Figure 5. Histogram Civics Learning Outcomes of Students Low Social Skills Using Problem Based Learning (PBL)

f. Score Frequency Distribution of Civics Learning Outcomes of Students with Low Social Skills Taught Using Expository

The results of the research conducted at the end of the experiment showed that for the treatment class the highest score was 27 and the lowest score was 10 . The frequency distribution analyzed using the Sturges technique obtained a range of 17 , many classes of intervals 5 , and class length 4 .

4 students (26.67\%) are in the interval $10-13,4$ students $(26.67 \%)$ are in the interval $14-17,3$ students $(20.00 \%)$ are in the interval $18-21,2$ students (13.33\%) are in the interval 22-25, and 2 students $(13.33 \%)$ is in the interval $26-29$. Distribution of scores. The [620] 
results of Civics learning outcomes for students with low social skills who are taught using the student expository above can be described as histograms as statistical diagram data as shown in Figure 6 below:

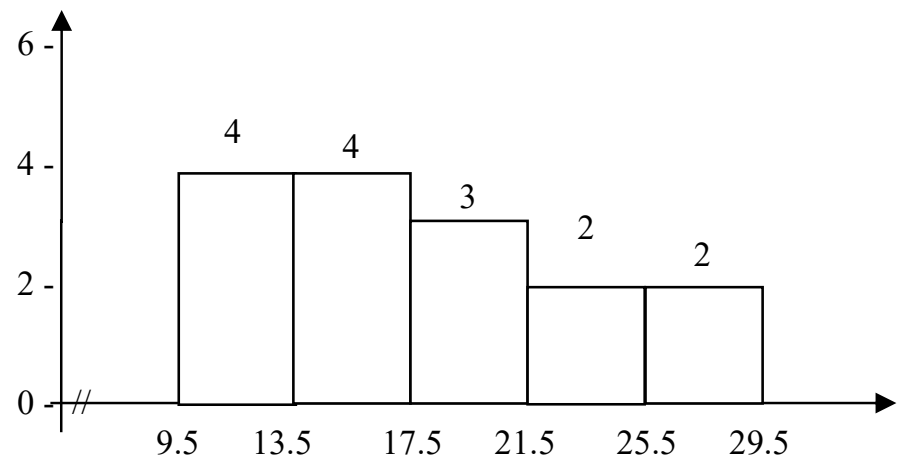

Figure 6. Histogram Frequency Distribution of Civics Learning Outcomes of Students with Low Social Skills taught by Using Expository g. Score Frequency Distribution of Civics Learning Outcomes of Students High Social Skills

The results of the research conducted at the end of the experiment showed that for the treatment class the highest score was 35 and the lowest score was 14 . The frequency distribution analyzed using the Sturges technique obtained a range of 21 , the number of class intervals 6 , and the length of class 4 .

3 students $(11,538 \%)$ are in the interval 14-17, 6 students $(23,077 \%)$ are in the interval $18-21,6$ students $(23,077 \%)$ are in the interval $22-25,6$ students $(23,077 \%)$ are in the interval $26-29,3$ students $(11,538 \%)$ are in the interval $30-33$, and 2 students $(7.6923 \%)$ is in the interval $34-37$. The distribution of scores. The results of the Civics learning outcomes of students with high social skills above can be described by histograms as statistical diagram data as shown in Figure 7 below: 


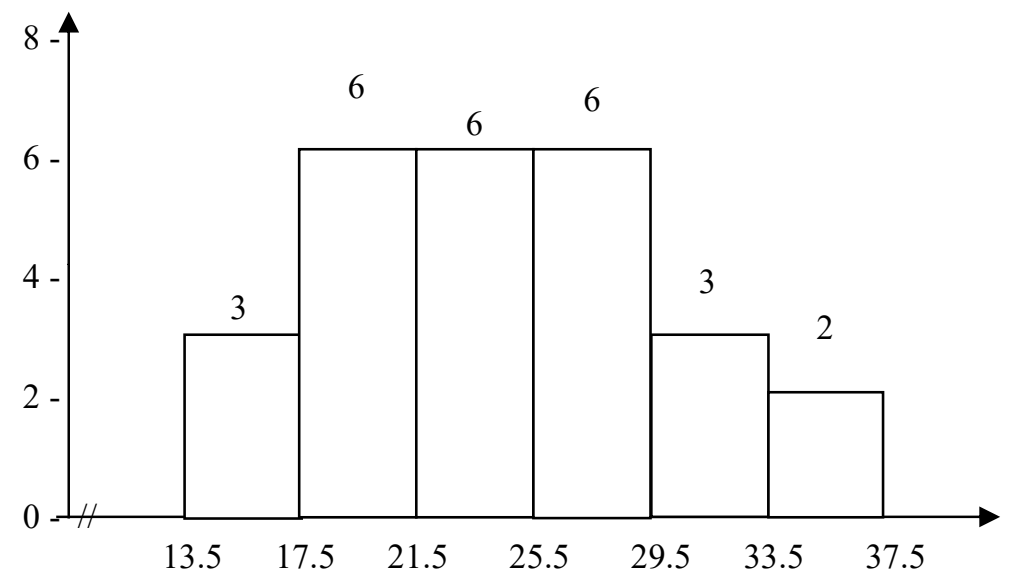

Figure 7. Histogram Frequency Distribution of Civics Learning Outcomes of Students High Social Skills

h. Score Frequency Distribution of Civics Learning Outcomes of Students Low Social Skills

The results of the research conducted at the end of the experiment showed that for the treatment class, the highest score was 31 and the lowest score was 10 . The frequency distribution was analyzed using the Sturges technique and obtained a range of 21 , the number of interval classes is 6 , and the length of the class is 4 .

4 students $(12.50 \%)$ are in the interval $10-13,8$ students $(25.00 \%)$ are in the interval $14-17,6$ students $(18.75 \%)$ are in the interval $18-21,6$ students (18.75\%) are in the interval $22-25,6$ students $(18.75 \%)$ are in the interval $26-29$, and 2 students $(6.25 \%)$ is in the interval of $30-$ 33, Civics learning outcomes of students with low social skills. The distribution of scores for the PPKn learning outcomes of students with low social skills above can be described by histograms as statistical diagram data as shown in Figure 8 below: 


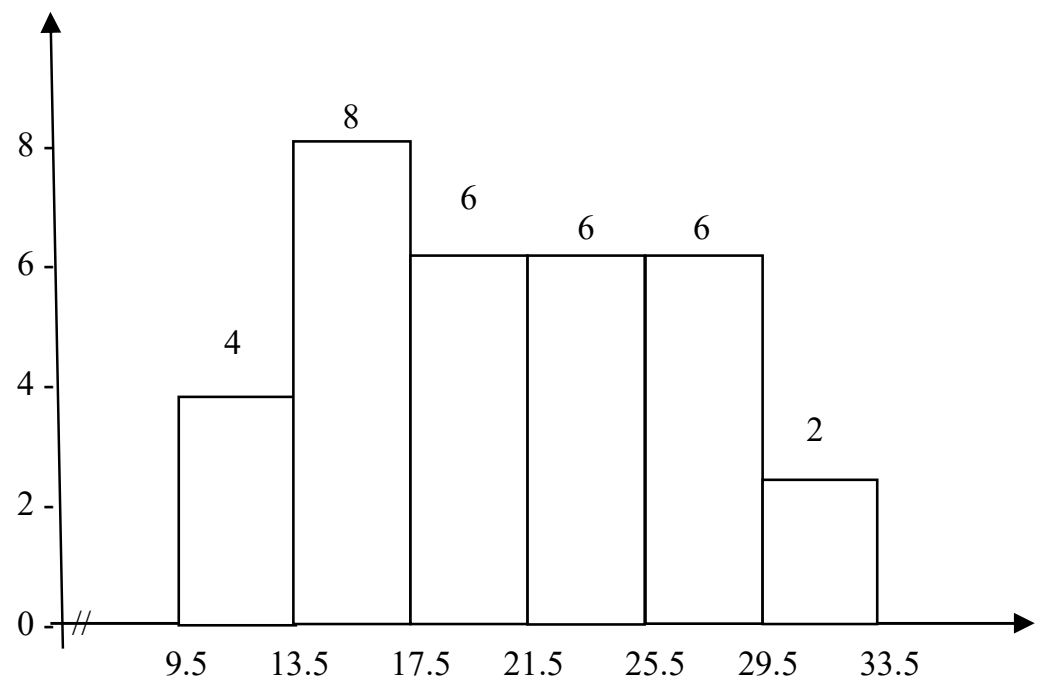

Figure 8. Histogram Frequency Distribution of Civics Learning Outcomes of Students Low Social Skills

\section{Discussion}

a. Student Civics learning outcomes by using learning Problem Based Learning (PBL) Higher than Student Civics Learning Outcomes by Using Expository Learning

Based on the data obtained above, it can be concluded that students Civics learning outcomes using Problem Based Learning (PBL) are higher than students Civics learning outcomes using Expository learning. This is in line with Schunk (2012) that constructivism theory is a learning theory that emphasizes the ability of students to build their own knowledge so that students tend to understand and analyze the knowledge they have. This means that students who are taught using Problem Based Learning (PBL) get higher Civics learning outcomes than students who are taught by Expository Learning.

Through Problem Based Learning (PBL) learning is expected to stimulate students to think actively to build understanding and ideas to 
find solutions to problems or solutions. This is in accordance with the opinion of Soejadi (2011: 43) who said that for Civics learning outcomes it is more appropriate if it is used or utilized in an environment that is close to the lives of students. In addition, students Civics learning outcomes using Problem Based Learning (PBL) learning can contain knowledge that is easy and can be imagined by students. This is in accordance with the view that a teaching material can be taught, among others, if it is related to the initial knowledge possessed by students.

Based on the discussion above, it can be concluded that Problem Based Learning ( $P B L)$ is better used in the learning process than expository learning in terms of solving problems, as well as in taking ideas that can improve Civics learning outcomes. Civics learning outcomes using Problem Based Learning (PBL) further activate students reasoning abilities and thinking abilities so as to enable students to more quickly understand the results of Civics learning given by the teacher.

b. Civics learning outcomes with High Social Skills are higher than that of Students with Low Social Skills

The results of this study are in line with the opinion of Gregore (2004: 150), the reality for thinkers with social skills is the world of metaphysical theory and high social skills thinking. People who have high social skills like to think in concepts and analyze information. Such a person will greatly value people and events that are orderly and neat. It is easy for them to observe important things such as key points and important details.

The results of hypothesis testing indicate that the social skills of students who use Problem Based Learning (PBL) are higher than those of students who use Expository learning, even though they are both Problem Based Learning (PBL) and Expository. It can be understood that in learning [624] 
to use Problem Based Learning (PBL) the new material is closely related to the material that has been studied by students previously, which is the material of PPKn learning outcomes. This is in accordance with the opinion of Sanjaya (2009:17) which says that each student has different abilities which can be grouped into high and low ability students. Students who are highly capable are usually shown by high social skills in learning, attention and seriousness in following lessons and so on.

c. Interaction Between Learning and Student Social Skills on Student Civics Learning Outcomes

The results of the analysis obtained, there are differences in the interaction of learning and social skills of students in influencing student learning outcomes of Civics. On average, groups of students who have high social skills and are taught using Problem Based Learning (PBL) have higher Civics learning outcomes than those using expository learning. Then on average, the results of the Civics learning group of students who had low social skills and were taught using Problem Based Learning (PBL) were lower than the group of students who had low social skills but were taught using expository learning. In other words, for groups of students who have low social skills, it is better to use expository learning compared to using Problem Based Learning (PBL), although the difference in PPKn learning outcomes is not significant. So in this case the learning and social skills of students are quite significant to affect the learning outcomes of students Civics in SDN 106161 Laut Dendang.

The experience gained by students in learning activities is the result of student activities while participating in learning. The acquisition of learning outcomes has many influencing factors. According to Rifa'i and Anni (2012: 80), there are 2 factors that influence learning outcomes, namely internal factors (from within) and external factors (from outside). 
In this study, the internal factors studied were social skills, namely learning outcomes in the form of pretest and posttest and emotional in the form of student learning activities. While the external factor studied is the use of learning models by teachers. The learning model is one of the important factors to achieve success in the learning process. Because the innovative learning model can activate students in learning so that the learning atmosphere will feel more alive. One of them is the cooperative learning model. Rusman (2014: 202) which defines that Problem Based Learning (PBL) cooperative learning is a form of learning in which students learn and work.

Based on the foregoing, the overall student learning outcomes for Civics were an increase in students abilities before and after treatment, especially in the treatment of Problem Based Learning (PBL). While in the Expository learning class, although there was an increase in Civics learning outcomes, the average increase in Civics learning outcomes was lower than the average value that had been implemented by using learning in Problem Based Learning (PBL).

\section{Conclusion}

Based on the results of the research and discussion previously stated, the following conclusions can be drawn:

1. The PPKn learning outcomes of students who received Problem Based Learning (PBL) were 24.37, which was greater than that of students who received expository learning of 19.46. That the results of student Civics learning by using Problem Based Learning (PBL) is higher than that of students by using expository learning. Through Problem Based Learning (PBL) it is hoped that it will stimulate students to think 
actively to build understanding and ideas to find solutions to problems.

2. Civics learning outcomes among students who have high Social Skills are higher than those of students who have low social skills. It can be seen that the Civics learning outcomes of students who have high social skills get an average score $=24.15$, while the Civics learning outcomes of students who have low social skills get an average score of 20.25. So it can be concluded that Civics learning outcomes among students who have high social skills are higher than the learning outcomes of Civics students who have low social skills. It can be understood that in learning to use Problem Based Learning (PBL) new material is closely related to the material that has been studied by students previously, which is the material for learning outcomes of Civics.

3. The results showed that there was no significant interaction between the use of learning and students social skills (high and low) in influencing Civics learning outcomes. It can be seen from the average value of each data group that the results of Civics learning of students who are taught with Problem Based Learning (PBL), namely the high social skills group (26.69), and the low social skills group (22.59), is greater if compared to students who were taught by expository learning, namely the high social skills group (21.62), and the low social skills group (17.60).

\section{Bibliography}

Asnawi, dkk (2017). Analisis Penerapan Pendekatan Saintifik pada Pembelajaran PKn untuk Meningkatkan Kecakapan Kewarganegaraan Siswa SD. Prosiding Seminar Nasional Pascasarjana (SNP) Unsyiah. 14(3): 64-69 
Fitriani, dkk. (2016). Peningkatan Keterampilan Sosial Siswa SD Melalui Penerapan Model Make A Match Berbantuan Kartu Bergambar. Jurnal Pendidikan Dasar. 5 (3) : 1-10

Ida, dkk. (2017). Pengaruh Implementasi Pendekatan Saintifik Terhadap Sikap Sosial Dan Hasil Belajar Pkn Di Kelas Vi Sd Jembatan Budaya, Kuta. Jurnal pascasarjana Universitas Ganesha. 4 (14) : 1-11

Kaswari, dkk. (2016). Pengaruh Model Pembelajaran Based Learning Terhadap Hasil Belajar Pkn Siswa Kelas V Sd. Jurnal Pendidikan Dan Pembelajaran. 5 (12) : 1-8

Rahmani. (2016). Penerapan Model Pembelajaran Inkuiri Terbimbing Untuk Meningkatkan Keterampilan Proses Siswa Sekolah Dasar. Tesis. Universitas Syiah Kuala Banda Aceh.

Ritongga, Mardiah. (2016). Pengaruh Model Pembelajaran Problem Based Learning dengan Peta Konsep dan Keterampilan Sosial Terhadap Hasil Belajar PPKn Siswa Kelas IV SD Negeri 116875 Rantauprapat. Tesis: Program Pasca Sarjana Universitas Negeri Medan.

Setiarini, Aries dkk (2016). Meningkatkan Motivasi dan Hasil Belajar Peserta Didik dengan Mengoptimalkan Penerapan Pendekatan Saintifik Strategi Discovery Learning dan Metode Diskusi di SDN Model Mataram. Jurnal Kependidikan 15 (3) : 1-9

Sugiyono, (2011). Metode Penelitian Pendidikan Pendekatan Kuantitatif, Kualitatif, dan $R \& D$. Bandung : CV . Alfabeta

Wayan, Ni dkk (2017) Evaluasi Diskrepansi Terhadap Implementasi Pendekatan Saintifik Pada Muatan Pelajaran Pkn Tema Cita-Citaku Di Kelas Iv Sd Se-Kecamatan Denpasar Timur. Jurnal Penelitian dan Evaluasi Pendidikan Indonesia. 7 (2) : 79-90

Wigunata Darma, dkk (2015). Pengaruh Pendekatan Saintifik Pada Mata

Pelajaran Pkn Terhadap Sikap Spiritual Dengan Kovariabel Intensitas Pola Asuh. Jurusan PGSD. 3 (1) : 1-10 